\title{
PAGALBOS IŠTEKLIAI SENATVINE DEMENCIJA SERGANČIO ARTIMOJO GLOBOS PROCESO METU: MOTERŲ-GLOBĖJU PERSPEKTYVA
}

\author{
ŽIVILĖ LUKOŠIENE் \\ VŠl KAUNO DAINAVOS POLIKLINIKA
}

Straipsnyje aptariamas moteru-globèju suvokimas apie pagalbos išteklius globojant senatvine demencija serganti artimaji. Tyrimas atskleide, kad globeju suvokimas apie pagalbos išteklius konstruojamas socialiniu paslaugu defamilizacijos stokos aspektu.

\section{IVADAS}

Lietuvos sveikatos informacijos centro (toliau - LSIC) $2011 \mathrm{~m}$. duomenimis, suaugusiųjų (nuo $18 \mathrm{~m}$.) sergamumas kraujagyslių ligomis sudaro 24,9\%. Demencija - susirgimas Alzheimerio liga, kuri prasideda iki 65 metų ir progresuoja reliatyviai greitai, blogejjant daugeliui aukštesniujju smegenų žievės funkcijų. Tai progresuojantis, degeneruojantis smegenų sindromas, paliečiantis atmintị, mąstymą elgesi bei emocijas. Lietuvos gyventojų sergamumas apskrityse ir savivaldybėse, $2012 \mathrm{~m}$. duomenimis, sergamumas Alzheimerio liga ir demencija vien tik Kauno mieste 1000 gyventojų tenka 6,7 atvejai. Lietuvoje užregistruota 25025 ligoniai, 1000 gyventojų tenka 7,8 atvejo. Globos įstaigu ir savarankiško gyvenimo namų seniems žmonėms ir suaugusiems asmenims su negalia $2011 \mathrm{~m}$. pabaigoje, pagal Lietuvos statistikos departamento informaciją (2012), buvo 100, jose gyveno - 4414 gyventojų. Ta pati statistika teigia, kad šiose istaigose užimta apie 94 \% vietų. Tad atlikus aritmetinius skaičiavimus, 
tarkim, 20 \% sergančiujų Alzheimerio liga ar kita demencija turètų galimybę pasinaudoti šių îstaigu paslaugomis. Neatsižvelgiant $i \mathfrak{t}$ tai, jog i šių ịstaigu gyventojų skaičių neįtraukti kiti senyvo amžiaus žmonės. Kitaip tariant, likusius artimuosius, sergančius demencija ir Alzheimerio liga, turi globoti šeimos nariai (Nausėdienė, 2007). Artimieji, globojantys sergantį šeimos narị, teikia jam neformalią globą (Whitlach, 1996). Globos procesas diktuoja globejjo vaidmenų kaita, užduotis ir atsakomybes (Archbold, 1983). Tai keičia globëjo gyvenima, šeimos santykius, fizinès ir psichinès sveikatos būklę (Užaitè, 2005; Jankūnaitè, 2009). Nagrinėdami globos procesa, tyrèjai konceptualizuoja globejjų našta, didelị krūvị (Savundranayagam, 2010), itampą globos procese (Nolan ir kt., 2002), globèjo ir jo šeimos narių išgyvenimus susirgus artimajam (Montano, 2011).

Globejo vaidmuo tampa lytiškai apibrèžtu konstruktu, sąlygojančiu moters vaidmeni globos proceso metu (Connell, 1987). Savo ruožtu kyla klausimas, kaip vis dèlto socialinès paslaugos gali prisidèti ir prisideda prie senyvo amžiaus žmonių globos ir taip sumažina artimuju patiriamą naštą. Tuomet svarbus tampa socialinių paslaugų defamilizacijos konceptas (Rauch, 2007, cit. Mažeikienė ir kt., 2013), kaip valstybès socialinių paslaugu igyvendintojo vaidmens atsakingas prisièmimas, nes taip suteikiama globejui galimybė pasinaudoti socialinėmis paslaugomis, nepriklausomai nuo šeimos sudèties bei artimų giminaičių (Mažeikienè ir kt., 2013).

Straipsnio tikslas - atskleisti pagalbos išteklius senatvine demencija sergančio artimojo globos proceso metu iš moterų-globejju perspektyvos.

\section{SENATVINĖ DEMENCIJA - SENYVO AMŽIAUS ŽMOGAUS GLOBOS POREIKIS BEI YPATUMAI}

Bendraja prasme senatvinè demencija - dažniausiai lètas protinių gebejjimų nykimas, sukeliantis atminties, mąstymo ir intelekto blogejjimą, galimą asmenybès irimą. Dažniausiai (bet ne išimtinai) ja serga vyresni nei 60 metų asmenys (Žydžiūnaitè, 2008). Viena labiausiai paplitusių senatvinės demencijos atmainų - Alzheimerio liga, kuriai atsirasti ir vystytis itakos turi genetiniai faktoriai, patirta galvos trauma, egzogeninè intoksikacija aliuminiu (Valeikienè, Skalskis, 2008).

Senatvine demencija sergantiji slaugantys artimieji rizikuoja atsiskirti nuo visuomenès, nes turi atsisakyti tam tikrų issipareigojimų, 
kartais - darbo ar išeiti atostogu, kad galètų rūpintis ligoniu. Susirgus artimiesiems, klostosi skirtingos situacijos, kurios priklauso nuo šeimos narių požiūrio ị ligonio priežiūros problemas. Šeima privalo gerai apgalvoti, ar yra pajègi prižiūrèti ligoni, turi įvertinti materialinę savo padèti, fizinius ir psichologinius aspektus (Jankūnaitè, Užaitė, 2011; Farran, 1997; AGİA, 2012).

Globejjišką paramą dažniausia teikia vyresnio amžiaus sutuoktiniai ir vidutinio amžiaus vaikai. Kai senyvo amžiaus žmogui prireikia pagalbos, pirmiausia kreipiamasi i sutuoktinius, paskui - $i$ suaugusius vaikus, draugus, kaimynus ir galiausiai - i pagalbos tarnybas. Jei sutuoktinio nèra arba jis dèl vienokių ar kitokių priežasčių negali globoti artimojo, globejjo vaidmens imasi suaugusi dukra (Lemme, 2003).

Neformalus senų žmonių globos procesas retai būna suplanuotas, numatytas iš anksto, aptarus ir pasirinkus, kas imsis globoti. Globa išsivysto palaipsniui, natūraliai, veikiama artimųjų tarpusavio santykių, palaikymo ir pagalbos patirties, susiformavusios gyvenimo eigoje. Globeju tampama daug anksčiau, nei žmogus identifikuoja save atliekant tą vaidmeni (Kinney, 1996).

Globos procese globejui kyla asmeninių sunkumų. Atliktų tyrimų duomenimis, šie sunkumai veikia globojančiojo psichinę ir fizinę sveikatą. Crossmanas ir kt. (cit. Lemme, 2003) slaugančius šeimos narius vadina "slaptomis aukomis“. Dažnas reiškinys, lydintis globejją slaugos procese, - depresija ir nerimas, susiję su lètiniu stresu slaugant ligonį. Stresas, kurị patiria slaugantysis, priklauso nuo įvairių kintamuju ų sąveikos: lyties, amžiaus, išsilavinimo, socialinės ekonominès padèties, profesijos, šeimos istorijos, sveikatos, šeiminės padėties, asmeninių savybių ir ryšių su globojamuoju. Tyrimų duomenys rodo, jog moterys dažniau kenčia nuo rūpesčių naštos ir psichologinio išsekimo (Savundranayagam ir kt., 2010).

B. H. Lemme (2003) aprašo stresą kaip dažniausią padarini, kurị sukelia globos aspektai. Tam didžiausią ittaką daro pasikeitę ryšiai su brangiu žmogumi. Stresą slaugančiajam sukelia pakitęs ligonio elgesys, labilios emocijos. Kitas veiksnys, autoriaus nuomone, sąlygojantis streso lygi globejui, - globos proceso poveikis šeiminiams santykiams. Šeimoje gali pasireikšti ịtampa, ribotos galimybès kartu praleisti laisvalaikị, didesnè rūpesčių našta, gyvenimo būdo pokyčiai ir finansiniai sunkumai (Lemme, 2003). 


\section{MOTERS VAIDMUO GLOBOS PROCESE: SOCIALINIŲ PASLAUGU DEFAMILIZACIJOS KONCEPTAS}

Darbų pasiskirstymą tarp lyčių kai kurie autoriai kildina iš skirtingų vyrų ir moterų polinkių, interesų lauko, bendravimo stiliaus ir igimtų bruožai, skirtingos „vyrų ir moteru“" prigimties. Anot C. Westo ir B. H. Zimmermano (1987), požiūris ì lyties prigimti suformuoja dvi lyties sąvokas: biologinès lyties kategoriją (angl. sex category) ir socialinę lyti (angl. gender). Biologinė lytis (angl. sex) apibrèžiama taikant biologinius diferenciacijos kriterijus, pagal kuriuos populiacija skirstoma i vyriškosios ir moteriškosios lyties individus (West, Zimmerman, 1987). Socialine lytis, priešingai nei biologiniai klasifikacijos kriterijai ir ju socialinè ekspozicija, yra socialinè veikla. Tai situacinis elgesys, valdomas normatyvinių sampratų, i̇vardijančių, kokie veiksmai ir nuostatos tinkami ir priimtini konkrečiai biologinès lyties kategorijai (West, Zimmerman, 1987).

Feminizmo idèjos glaudžiai susijusios su kritiniu socialiniu darbu, aptariant socialinių paslaugų modelius socialinès gerovès valstybėse. Čia labai svarbi sąsaja tarp feminizmo, kritinio socialinio darbo bei feminizmo atrandama N. Mažeikienės, R. Naujanienės, J. Ruškaus, R. Motiečienės, D. Dvariono, D. Žvirdausko (2013) nepublikuotoje monografijoje apie igalinančių socialinių paslaugų modelio konstravimą. Joje tyrinejjamas inovatyvių socialinio darbo paslaugu modelis Lietuvoje, plètojamos socialiai pažeistų visuomenès grupių igalinimo strategijos. Tyrèjai analizuoja skandinavišką socialinès gerovès modelį, kurio vienas esminių konceptų - globos paslaugų defamilizacija (Rauch, 2007, cit. Mažeikienè ir kt., 2013). Monografijos autoriai pirmieji Lietuvoje aprašo bei aptaria ši konceptą. Globos atsakomybès defamilizacija suprantama kaip šeimos atlaisvinimas nuo pareigos suteikti globos paslaugas. Kartu aiškiai suvokiama: žvelgiant kultūriniu aspektu, šeimos įsipareigojimas suteikti globą natūraliai priskiriamas moteriai, tradiciškai susiejus globos funkciją su moterišku darbu. Be to, defamilizacijos samprata leidžia suteikti klientui prieigą prie paslaugos nepriklausomai nuo šeimos santykių, nuo savo giminaičiu (Mažeikienè ir kt., 2013). Skandinaviškam modeliui būdingas siekis maksimaliai įtraukti žmones î darbo rinką užtikrinti lyčių lygybę; valstybė prisièmė atsakomybę už šeimos narių, negalinčių pasirūpinti savimi, priežiūrą (Woods, 2006). Defamilializacijos principas 
(Woods, 2006) teigia: prieš pradedant kalbèti apie lyčių lygybę ir moters konkurencingumą darbo rinkoje lyginti su vyro, pirmiausia reikia moteri atlaisvinti nuo namų ūkio bei artimuju globos atsakomybės bei pareigų. Taip sudaromos sąlygos šeimos nariams - ir būtent moterims - dalyvauti darbo rinkoje. Valstybè tampa pagrindine dalyve, teikiančia visuotines socialines paslaugas ir pagrindini pragyvenimo minimumą visiems piliečiams (Mažeikienè ir kt., 2013).

Pagal LR istatymą dèl socialinių paslaugų katalogo patvirtinimo (Nr. A1-93, 2006 m., Vilnius, VŽ, Nr. 43-1570), socialinès paslaugos skirstomos į bendrąsias ir specialiąsias (II dalies, 4 punktas). 1 lentelëje pateiktos socialinès paslaugos, kurių gavėjai yra senyvo amžiaus asmenys ir jų šeimos (bendrosios socialinès paslaugos), ir senyvo amžiaus asmenys (specialiosios socialinès paslaugos).

1 LENTELĖ. LR SOCIALINÉS APSAUGOS IR DARBO MINISTRO İSAKYMAS DĖL SOCIALINIŲ PASLAUGŲ KATALOGO PATVIRTINIMO (2006)

Bendrosios socialinės paslaugos

1. Informavimas

2. Konsultavimas

3. Tarpininkavimas ir atstovavimas

4. Maitinimo organizavimas

5. Aprūpinimas būtiniausiais drabužiais ir avalyne

6. Transporto organizavimas

7. Sociokultūrinès paslaugos

8. Asmeninės higienos ir priežiūros paslaugų organizavimas

9. Kitos bendrosios socialinès paslaugos

Specialiosios socialinės paslaugos

\begin{tabular}{l|l}
\hline \multicolumn{1}{c|}{ Socialinė priežiūra } & \multicolumn{1}{c}{ Socialinè globa } \\
\hline 1. Pagalba ị namus & 1. Dienos socialinė globa \\
\hline $\begin{array}{l}\text { 2. Socialinių igūdžių ugdymas ir pa- } \\
\text { laikymas }\end{array}$ & 2. Trumpalaikè socialinė globa \\
\hline $\begin{array}{l}\text { 3. Apgyvendinimas savarankiško gy- } \\
\text { venimo namuose }\end{array}$ & 3. Ilgalaikè socialinè globa \\
\hline 4. Laikinas apnakvindinimas & \\
\hline 5. Intensyvi krizių ìveikimo pagalba & \\
\hline
\end{tabular}


2012 m. birželio 29 d. informaciniame pranešime Lietuvos statistikos departamentas pateikia, kad $2011 \mathrm{~m}$. pagalbos į namus ir socialinės globos asmens namuose paslaugos buvo suteiktos 15 tūkst. žmonių, arba šeštadaliu (17 \%) daugiau nei 2010 m. Kaip ir ankstesniais metais, dauguma $(81 \%)$ socialinių paslaugų namuose gavejų buvo senyvo (pensinio) amžiaus asmenys. Palyginti su 2010 m., šias paslaugas gavusių senyvo (pensinio) amžiaus asmenų skaičius padidejo 12 \%. 2011 m. 292 senyvo amžiaus ir neigaliems žmonėms buvo išmokèti pagalbos pinigai ir jie patys organizavosi socialinių paslaugu teikimą namuose. Palyginti su 2010 m., šios išmokos gavejju sumažèjo 12 \%. 2011 m. pabaigoje veikè 100 globos îstaigų seniems žmonėms, kuriose buvo 4,7 tūkst. vietų. Gyventi pas artimuosius ar gimines išvyko 91 senelių namų gyventojas. $2011 \mathrm{~m}$. pabaigoje senelių globos namuose gyveno 4,4 tūkst. gyventojų. 2011 m. pabaigos duomenimis, globos įstaigose ir savarankiško gyvenimo namuose seniems žmonėms ir suaugusiems asmenims su negalia buvo 4414 vietų. Savivaldybiu globos îstaigose buvo 3009 vietos, iš ju užimta 94,6 \%. Toliau pagal vietų skaičiu eina visuomeninès organizacijos, parapijos ir privačios globos įstaigos, turëjusios 1238 vietas, kurių 92,2 \% buvo užimta. Kitos valstybinès ir nevalstybinès senų žmonių globos i̇staigos turi žymiai mažiau vietų ir beveik visos jos yra užimtos, (Lietuvos statistikos departamentas, 2012).

\section{TYRIMO METODOLOGIJA}

Pasirinktam sergančio artimojo globos šeimoje fenomenui tirti taikytas kokybinis tyrimas, arba subjektyvistine interpretuojamoji epistemiologija, remiamasi K. Charmazo (2011) konstruktyvistinès grindžiamosios teorijos versija, smarkiai atitolusia nuo pozityvistinių prielaidų ir dèmesi nukreipusia ị studijuojamą fenomeną. Socialinių tyrimų filosofijos, kuriomis remiasi šis subjektyvistinès interpretuojamosios analizès metodas, yra konstruktyvizmas ir interpretatyvizmas. Konstruktyvistai akcentuoja interpretacini duomenų aspektą (Charmaz, 2011).

Pasirinktas kriterinès tyrimo imties sudarymo būdas (Bitinas ir kt., 2008): sergančiojo senyvo amžiaus šeimos nariui turètų būti diagnozuota Alzheimerio liga arba kita demencija, globa turètų trukti ne mažiau nei vienus metus, globėjas - darbingo amžiaus sūnus ar duktė. 
Tyrimo dalyvių vidutinis amžius - apie 51 metai. Artimojo globos vidutinè trukmé - apie 5 metus. Trys tyrimo dalyvės yra susituokusios, gyvena su vyru ir paaugliais vaikas. Dvi tyrimo dalyvės išsiskyrusios, gyvena su kitais vyrais. Vienos tyrimo dalyvės duktė gyvena užsienyje. Viena tyrimo dalyvė vaikų neturi.

Tyrimo duomenims gauti naudotas giluminis teminis interviu (Tidikis, 2003). Nestandartizuoti (giluminiai) interviu - tai interviu, kai iš anksto neformuluojami galimi atsakymų variantai, dalyviams paliekama galimybė atsakymus formuluoti patiems, naudojami „,atviri“ nenukreipiantys klausimai (Tidikis, 2003).

Duomenys analizuoti remiantis grindžiamosios teorijos metodu. Grindžiamosios teorijos, kaip duomenų analinès metodo, tikslas - kurti kategorijų rinkinius, nustatyti kategorijų, išskirtų iš turimų duomenų, ypatybes, sujungti tas kategorijas į tam tikrą teoriją. Duomenys analizuoti keliais etapais. Pirmuoju etapu jie buvo koduojami: naudotas atviras kodavimas, kuriuo kokybiniai duomenys suskirstyti i kategorijas, kad yra tinkami tolesnei analizei (Krysik, Finn, 2010). Tyrëjas atidžiai skaitė kiekvieną eilutę, rinko ir žymėjosi reikšminius žodžius, vẻliau šalia ju ar sakinių paraštėse užrašè mintis, pastabas, reakcijas. Taigi tyrimo duomenys buvo skaitomi keletą kartų, vis ieškant naujų, dar neatpažintų raktinių reikšmių (Krysik ir kt., 2010). Kitas tyrimo duomenų analizės etapas - kategorijų išskyrimas (Willig, 2008). Kategorijos buvo įvardytos 1-2 esminiais žodžiais, atsižvelgiant i ankstesni kodavimą. Taip kelis kartus buvo peržvelgtas kiekvienas interviu ir išskirtas kategoriju rinkinys. Po to kategorijos detalizuotos ir suskaldytos i subkategorijas, kitaip tariant, buvo atpažǐstamos ar numanomos kategoriju ypatybès, dimensijos, ieškota panašumų ir skirtumų tarp kategorijų, t. y. atlikta lyginamoji analizė (Willig, 2008). Vèliau subkategorijų forma užpildoma in vivo turiniu ar interviu išrašo kopija, tyrimo dalyvių tiesiogine kalba. Kitaip tai yra emic perspektyva - tyrimo dalyvių ižvalgos, susijusios su konkrečia subkategorija (Willig, 2008). Šiame tyrimo analizės etape, vadinamame etic perspektyva, pereinama prie teorinio jautrumo, arba analitinio etapo. Tai tyrejjo iž̌valgu perspektyva, mintys, idejjos, jausmai, sąsajos su teorija. Nuo aprašomojo pobūdžio pereinama prie analitinio, interpretuojamojo, t. y. sąveikaujama su tyrimo duomenimis (Willig, 2008). 


\section{PAGALBOS ŠALTINIAI GLOBOS PROCESE}

Aplinkiniu pagalba globos proceso metu: "nei vienas negalim suprasti to, ko patys nesame patyre...."

Tyrimo dalyvė Marija sako, kad jos vyras visai nedalyvavęs su globa susijusiose kasdienėse veiklose. Bet moteris pati sąmoningai jị atstūmè: esa, tai jos mama ir ji pati turinti prisiimti visą atsakomybę ir pareigas. Kitas aspektas, moters akimis, yra tas, jog vyras neturi užsiimti veiklomis, susijusiomis su moters priežiūra, higiena. Tyrimo dalyvei labiausiai gelbèjo vakariniai vyro pašnekesiai su sergančia mama, kurių ji labai laukdavusi, ir tai buvo labai reikalinga. Globejjos įžvalga ir vertybės labai aiškios - tai jos mama, jos pareiga rūpintis ir kuo mažiau įtraukti vyrą ir vaikus.

Vyras visai nesikišo ị mamos priežiūra. Aš pati kažkaip jị atitraukiau, vienas dalykas - čia mano mama ir aš turiu pati pasirūpinti, kitas dalykas - jis vyras - negi jam apie moteri suktis... Jis tik griždavo vakaris po darbo ir pasikalbédavo su mama, kaip jai diena, kaip sveikata... mamai to labai reikédavo, nes ji kažkaip labai gerbe mano vyra... [Marija, 39 metai].

Tyrimo dalyvė Beata pasakoja, kad jai pagelbėdavęs pažistamas vyriškis. Jie kartu ikeldavę ir pasodindavę mamą i foteli, apkamšydavę antklodèmis. Gydymo istaigoje jai buvo primygtinai siūloma atiduoti mamą i slaugos institucija nes pati nepajégsianti susidoroti. Tuo metu Beatai nepavyko rasti slaugos ligoninès - nebuvo laisvų vietų. Tada pažistamas pasiūlè vežtis sergančią mamą namo ir pažadejo padèti ja rūpintis. Vyras keldavosi naktį, kad pasodintų mamą; nunešdavo iki greitosios pagalbos automobilio. Moteris labai dèkinga šiam vyrui, nes tik jo dèka galëjo rūpintis mama namuose. Tyrëjas įžvelgia, kad moteris džiaugiasi ir yra dèkinga, jog visai svetimas žmogus taip labai padejjo jai prižiūrèti mamą nesiskųsdamas, netausodamas savęs.

Jau vakare draugas va ateidavo, jau keldavau i foteli, i kaldras isukam. Ir pasodinu taip, kad jinai šiek tiek, nu, ta kraujotaka kad pasikeistu, <...> tik $i j$ ji ir atsiremdavau. $<. .>>$ ligoninej man jau sake, kad turit atiduot $i$ slaugos ligonine, nes viena nesusitvarkysit. <...> Ir jisai man sako, vežkis namo ir padesiu. <...> Ir keldavosi naktị ir ja sodinti. <...> Tai čia jau mano rankos buvo. [Beata, 60 metų].

C. Whitlatchas ir L. Noelkeris (1996) išskiria pagrindinius ir antrinius globos teikejjus. Pagrindiniais šiuo atveju tampa duktè ar sūnus, 
aplinkybių ar kitų motyvų skatinami prisièmę globėjo vaidmenį. Antrines globos teikëjų veiklas dažniausiai atlieka pagrindinio globėjo suaugę vaikai, broliai ar seserys, bendruomenès nariai. Dažniausiai tos veiklos padeda pagrindiniam globejui atlikti kasdienes užduotis, susijusias su sergančiojo poreikiais. Tai vadinama neformaliomis arba natūraliomis pagalbos sistemomis. J. Pivorienè (2004) laiko šeimą pagrindine neformaliosios pagalbos šaltinio dalimi, kuriuo globejas naudojasi pirmiausiai globos proceso metu. Kitomis šio neformalaus pagalbos šaltinio dalimis tampa giminaičiai, draugai, bendruomenè. Pagal sistemų teorija vienos sistemos dalies elemento funkcionavimui sutrikus ar pakitus, keičiasi ir kitų sistemos sudedamųjų elementų funkcionavimas. Žvelgiant i i šeimą kaip sistema, pasikeitęs globejjo vaidmuo ir atsiradusios kitos veiklos turejjo įtakos jo elgesiui ir gyvenimo būdo pokyčiams. Taip kinta ir kitu šeimos narių gyvenimas, todèl jie stengiasi prisidèti prie globejui keliamų globos proceso reikalavimų, kad pusiausvyrą būtų kuo greičiau atstatyta. Labai svarbu, koki socialinį tinklą turi globejjas ir jo šeima: jei jis pakankamai platus ir ivvairialypis, jame ieškoma neformaliu pagalbos išteklių - kreipiamasi pagalbos i giminaičius, draugus, gyvenamąją bendruomenę. Šio tyrimo dalyvès apsiribojo instrumentine neformaliuju šaltinių pagalba (Lemme, 2003).

\section{Formaliosios pagalbos šaltiniai globos procese: tarp norų ir galimybių}

Žmonès kreipiasi pagalbos į formaliuosius pagalbos išteklius pajutę negalintys patenkinti pagrindinių poreikių ir patys nepajėgiantys toliau normaliai funkcionuoti, kai atsiranda įvairių įtampų: psichologinè, socialinè, fizinė, kyla konfliktų, žmonès nesugeba atlikti kasdienių savo pareigu, nepakelia užgriuvusios atsakomybės (Lukoševičienė, 1996). Globejjai, išbandę ir naudojantys neformaliuosius pagalbos išteklius, ilgainiui pastebi, jog situacija šeimoje lieka įtempta ir emocinę pusiausvyrą išlaikyti vis dèlto yra sudètinga. Tuomet globejjai bando ieškoti išorinių formaliųjų pagalbos šaltinių. Aplinkybių verčiamos ar savo noru prisièmusios globejuc vaidmeni, tyrimo dalyvės kartu prisiima ir visišką tik savo pačios atsakomybę už sergantij]i. Globą jos mato iš tradicinės patriarchalinès perspektyvos, kai sergančio artimojo slauga yra tik jų pareiga ir atsakomybè. Todèl globos proceso pradžioje ir vèliau moterys deda visas savo fizines ir emocinès jègas, kad kuo ilgiau galètu savarankiškai pasirūpinti sergančia mama. Pagalbos šaltiniai matomi 
ir naudojami dažnai tik tuomet, kaip savo jẻgų nebepakanka. Būtina pabrèžti, jog kalbama apie fizines globejos jègas. Kilus emociniams sunkumams susidoroti su globos proceso našta, globejai retai kreipiasi pagalbos ị kitus šaltinius, bando pasikliauti savo jègomis (Žydžiūnaitė, 2008; Jankūnaitė, Užaitè, 2011).

Nomeda dalijasi patirtimi, kaip sekėsi tvarkyti formalius dokumentus, susijusius su mamos globa bei globejo padètimi. Moteris teigia jokios informacijos, kas jai priklauso įstatymiškai pagal esamą statusą, iš nieko negavusi. Tuomet paklausė Sodros darbuotojų ir sužinojo tokią procedūrą: ji kreipiasi i teisma, kur pirmiausia nustatomas artimojo neveiksnumas. Per antrą teismini procesą sergančiam artimajam nustatoma globa. Buvo paaiškinta, kad šis procesas užtruksiąs apie metus. Moteris sutriko, ar tai realu: metai laiko jos mamai (esant tokios sveikatos būklès) yra labai ilgas laiko tarpas - ji galinti tiek neišgyventi. Tuomet jai pasiūlyta net nepradèti teisminès bylos, apgailestauta, kad įstatymai esą būtent tokie ir šioje situacijoje specialistai negalintys niekuo pagelbèti. Dar kartą pabrèžta: jei globejja vis dèlto norèsianti pradèti teisminę procedūra, turinti nusiteikti, jog procesas truksiąs apie metus. Tyrimo dalyvè pasidomèjo, kas nutiksia, jeigu ji vis dèlto nespèsianti šios bylos užbaigti, sulaukti teismo nutarties, jei mama neišgyvensianti iki to laiko. Atsakyta, jog teismo darbuotoju praktikoje tokių bylų nutrūksta labai daug dèl sergančiojo mirties. Čia tyrëjas ịžvelgia globejos patirtị, su kokiais sunkumais, su kokiu požiūriu jai teko susidurti, norint įteisinti savo padètį.

Niekur... niekas mums nieko nepasako. <..> Bet kai aš pradejjau vaikščioti i socialinès rüpybos skyriu aiškintis, kad pareiškè, jog viskas yra per teisma. <...> Kreipiausi i savivaldybę, pareišké, kad jūs dèl stažo kreipkitès ị Sodra. Kreipiausi i Sodra ir prasidejo ratas iš naujo. Pasakè, jūs turite duoti, žodžiu, prašyma i teisma, kad mamai nustatytu... neveiksnuma. <...> Bet, sako, visa ta procedūra truks metus laiko. Aš dar paklausiau, ar tai gali büti realu, kad senam žmogui, vat, nustatyti tuos dalykus. Metai laiko, sakau, tokio amžiaus, kaip mano mama, metus laiko jeigu išgyvena, tai čia jau reikètu labai džiaugtis. Tai sako, tai žinot, gal jūs tada net nepradékit... <...> jie sako, aš jus suprantu, bet tokie yra istatymai. [Nomeda, 47 metu].

Globeja teigia, kad tuo pokalbiu jos bandymai ir baigèsi. Jeigu pradèsianti teismini procesa, tai atimsią iš jos daug laiko ir energijos, tuomet ji negalèsianti pakankamai jègu, dėmesio, laiko skirti savo šeimos nariams 
bei sergančiai mamai. Pradžioje moteris dar svarstė ieškoti kur nors pagalbos, kad atvažiuotų, pasižiūrètų ir įvertintų, kokia dabar yra jos mamos padètis. Moters manymu, tuomet nekiltų klausimas, ar ligonè veiksni, ar ne. Tuomet, svarstė ji, teismo procesą galètų paskelbti pradètą jau po savaitės ir viskas vyktų greičiau. Specialistai globėjos pasidomejjo, ar ji žinanti, kiek panašių ir kitokių bylų yra teismuose. Tuomet tyrimo dalyvė sako suvokusi, kad įstatymai sukurti ne tarnauti ir padèti žmogui. Ji liovėsi domėtis galimybėmis ir pasidavè. Paklausè specialistų, kam, ju nuomone, kuriami tokie įstatymai, kad sergantis žmogus mirtų ir globejjas nesulauktų galimybės pasinaudoti savo teisėmis. Moteris drąsiai teigè nusivylusi formalios teisinès bei socialinès pagalbos sistema ir šiuo metu „sustojusi“ ieškoti pagalbos. Nomeda svarsto pasiieškoti darbo, pati tvarkytis namuose ir prižiūrèti sergančią mamą tikẻdamasi, jog pavyksią kaip nors išgyventi. Teigia daugiau nebenorinti kreiptis pagalbos i miesto savivaldybę. Tyrèjui akivaizdu, kad pokalbiuose su teisinès, socialinès sistemų specialistais moteris išgirdo neišsakytą mintį, jog procesai, leidžiantys įteisinti globejjos statusa, trunka ilgai ir neretai lieka nebaigti. Nomeda suprato padėsianti daug jėgu, laiko, kurie bus atimti iš artimujuu. Čia svarbu paminèti, kad globejjas paliekamas vienas susidoroti su savo sunkumais. Kitaip tariant, sergančio artimojo globa yra pareiga, atsakomybè, nesvarbu, kiek tai kainuoja globejui ir jo šeimai.

Tai praktiškai tuo ir baigèsi, nes aš galvojau, jeigu aš energija savo naudosiu teismams, man jos pritrūks šeimai, pritrūks mamai. Tiesiog, na, aš buvau labai pasipiktinus, iš pradžiu galvojau, gal kažkur tai klaust, ar negali tiesiog atvažiuot pamatyti ta žmogu. Ten veiksnumas, neveiksnumas net klausimu nekiltu. <...> Tai pasakè, ar jūs žinote, kokios dabar teismuose eilès? Tai aš taip supratau, kad istatymai ne žmogui. Na, iš tikruju aš tada nutraukiau viska, ta reikala ir viskas taip baigési. <...> Nusivyliau iš tikruju visu tuo ir tiesiog šiuo metu aš sustojau, sakiau, gal geriau pasiieškosiu darbo, pasisukiosiu kaip nors pati namuose, ir gal kaip nors išgyvensim. [Nomeda, 47 metu].

Tyrèjas sąmoningai uždavè klausimą apie socialinius darbuotojus ir moteru patirti bendraujant su jais. İdomu tai, kad pasakodamos nè viena moteris nekalba apie socialini darbuotoja jo funkcijas, pagalbą. Tyrimo dalyvè Rita sutriko, trumpai stabtelèjo pamąstyti ir bandè prisiminti. Moteris sako, jog niekas jai nesiūlęs socialinio darbuotojo paslaugų, kuris gyventų jų mikrorajone ir galètų ateiti i pagalbą. Sako, kad jai ir 
nereikejję tokios pagalbos. Dabar ji teigia radusi savo rajone psichikos sveikatos centrą. Globeja ketina tame centre pasidomèti socialinio darbuotojo veiklomis. Suvokia, jog reikia pačiai ieškoti pagalbos, niekas neateisiąs ir nepasiūlysiąs. Globejos akimis, mūsų šalyje nèra tokios socialinių paslaugų sistemos, kad susirgus artimajam ir šeimos nariams turint priimti globejo vaidmeni, socialinis darbuotojas tarsi atsiranda savaime ir pasiūlo savo paslaugas. Tai atrodo nerealu, tartum nušvitimas. Tyrejjas ižzvelgia, kad moteris sutrinka kalbėdama apie galimą socialinio darbuotojo vaidmeni globos procese: ji tiesiog nežinanti, kur ieškoti šio specialisto, kuo jis gali padèti. Ji nemato socialinio darbuotojo vaidmens globos procese. Ir tik tyrejjui paklausus apie šios srities specialista, moteriai kyla mintis, kur galima jo ieškoti ir pasidomèti apie teikiamas paslaugas.

Nes man niekad ir nesiūlè, kad vat iš N kažkoks socialinis darbuotojas būtu, kad... vat tikrai aš... ne... nebendravau. <..> gal ten yra ir kažka tai reikia pradèt išsiklausinèt, domètis. Nu, savaime nieks neateis i namus. Nèra tokia sistema. Va, susirgo mano mama ir staiga man paskambina socialinis darbuotojas ir pasiūlo pagalba... [Rita, 53 metai].

Tyrimo dalyvė Nomeda pasakoja, kad jai labai trūkę informacijos. Ji nežinojusi, kad yra slaugos darbuotoju, kurie gali ateiti pagelbėti, išmaudyti ligoni. Globėja svarsto, jog sergantị artimajị slaugantys žmonės tiesiog palikti likimo valiai. Moteris sako pasakojusi šeimos gydytojai, kaip jai sunku atlikti kasdienes mamos higienos procedūras - medikè tylejusi. Nomeda stebisi, kad gydytoja net nebandè svarstyti, kaip pagelbèti. Tuomet ji suvokè, jog sergančios mamos globa yra tik jų šeimos reikalas. Čia vèl labai ryškus tyrimo dalyvès požiūris i formalius pagalbos šaltinius - trūksta informacijos, nebandoma ieškoti pagalbos išteklių.

Informacijos atžvilgiu, nes man jos be galo trūko, nes aš nežinojau, kad yra tokie slaugos darbuotojai, kad aš galiu gal pasikviesti, kad išmaudyt padètu. $\mathrm{Na}$, aš nežinau, ka tokiu atveju daryt, nes man toks jausmas, kad tie žmonés yra palikti likimo valiai, tie, kurie slaugo... Aš gydytojai pasiskundžiau, kad man labai sunku išmaudyti, ji tyli... Jinai tyli, man nieko nepasako, kad gal kažkoki tai varianta padètu ar kaip. Tai aš supratau, kad tai, kad tai, na, ne jos reikalas. [Nomeda, 47 metu]].

Tyrimo dalyvę Mariją sutrikdė tyrèjo domėjimasis apie pageidaujamą, reikalingą pagalbą jai - moteris kelis kartus pasitikslina klausimą. Ji 
abejoja, ar kas nors gali jai padėti. Globejja svarsto, jog kasdienes su mamos priežiūra susijusias veiklas ji galinti atlikti pati. Pamąsčiusi nutaria, kad labai didele pagalba būtų, jei kas nors ateitų bent kartą per savaitę ir pabendrautų su sergančia mama. Galbūt tuomet mama būtų ramesnè, grįžus mergaitėms iš mokyklos ir tėvams iš darbo nereikalautų dėmesio, nes visi ir taip būna pavargę po dienos rūpesčių ir užduočių. Dar vienas pagalbos poreikis - jei kas nors išvestų mamą pasivaikščioti i gryną ora, nes tam irgi reikia laiko ir jègų. Tyrimo dalyvẻ tarsi teisinasi žinanti, jog mamai reikalingas grynas oras ir būtina pasivaikščioti, nes nuolat būti patalpoje nèra gerai. Tačiau norėdama po darbo atlikti namų ruošos darbus, pasirūpinti būtiniausiais šeimos narių poreikiais, ji nebespėja išvesti mamos į lauką ir dẻl to jaučiasi labai kalta. Pagalvojusi moteris labai aiškiai įvardija savo bei mamos poreikius, kuriuos patenkinus, manoma, visa šeima patirtų mažiau įtampos, nerimo, pykčio bei kaltès jausmų.

Tai kad net nežinau, ar čia galètu kas kaip nors padèti... Kažkaip ten apiprausti, numaudyti tai ir pati kažkaip susitvarkau... <...> labiausiai tai norètusi, kad kažkas ateitu bent kelis kartus per savaite ir su ja pasikalbètu, išklausytu... gal tada ji būtu ramesnè, nereikalautu müsu tiek daug dèmesio... Arba, kad, tarkim, išvestu ja geru oru pasivaikščioti... juk tam irgi reikia ir laiko, ir jègu. Žinau, kaip ji nori tyro oro, kai ji dūsta čia, kambary, bet per tuos namu ruošos darbus aš tikrai nebespeju dar ir pasivaikščioti su ja... [Marija, 39 metai].

Tyrimo dalyvė Rita drąsiai ir užtikrintai teigia, kad jai labiausiai reikètų, jog kas nors užsiimtų sergančia mama. Tuomet ji jaustųsi rami. Moteris teigia, jog jai visiškai nesvarbūs mamos protiniai gebejjimai - svarbiausia, kad ji mokètų atlikti kasdienes veiklas, susijusias su jos pačios gerove. Svarbu, kad globejjai išèjus į darba, mama sugebėtų saugiai užsivirti vandens arbatai, naudotis dujine virykle, pasigaminti lengvai paruošiamą maisto patiekala, galop, atlikusi gamtinius reikalus, nuleistų vandeni tualete. Ir apibendrina - tiesiog susitvarkytų. Rita nenori nerealiu ar sunkiai igyvendinamų dalyku, jos akimis, ji tik norinti jaustis saugi. Nori išẻjusi i darbą žinoti, kad galinti ramiai palikti mamą vieną namuose, kad ji sugebėsianti pasirūpinti savo esminiais fiziologiniais poreikiais nesukeldama grèsmès nei sau, nei namams. Moteris teigia, jog dabar esantis nesaugumo jausmas yra baisus. Tyrëjas įžvelgia, kaip globejjai svarbu, kad jai esant darbe kažkas suteiktų pagalbą ir pasirūpintų sergančia mama. 
Pagalbą ji įsivaizduoja kaip kasdienių sergančiojo igūdžių ugdymą kad jis galètų pasirūpinti savimi nekeldamas grèsmės sau ir aplinkiniams.

Kad kas nors su ja užsiimtu. <...> man labai svarbu, kad jinai užsikaistu arbatos, kad jinai dujom naudotusi normaliai, kad jinai galètu kiaušini išsikepti, kad tualete pasinaudojus ji nuleistu vandeni... Ir aplamai susitvarkytu... <...> Nenoriu kažkokio ypatingo dèmesio, bet nèra saugumo jausmo. Va šitas baisu... [Rita, 53 metai].

Tyrimo dalyvės pabrèžia, kad vienas svarbiausių lūkesčių naudojantis formaliais pagalbos šaltiniais - gauti informacijos, kuri padètu ịveikti ittampa, nerimą ir stresą (Jankūnaitė, Užaitė, 2011). Profesine veikla užsiimančių tyrimo dalyvių nuomone, labai svarbi pagalbos galimybè specialiosios institucijos ar specialistai, kurie galètų užimti sergantị artimajji tam tikrą dienos dalį. Tuomet atkristų vienas didžiausių rūpesčiu ir būtų patenkintas svarbus sergančio artimojo bendravimo poreikis. Vienos tyrimo dalyvè pageidauja pagalbos ruoštis namuose, kad galètų pailsinti savo fiziškai skaudantį kūną.

Ateities vizija: "jau dabar jūs jau man turèsit patarti..."

Tyrimo dalyvė Rita interviu pabaigoje užsimena, kad ją nuolat apima mintys ir jausmas, jog kažkada teks atsisakyti darbo ir likti namuose prižiūrèti sergančią mamą. Tačiau moteris ketina visais būdais bandyti išlaikyti darbinę veiklą. Globejja svarsto galimus variantus - samdyti svetimą žmogu, ieškoti specializuotu îstaigų pagalbos, kur galètu palikti mamą dienos metu, kol dirba. Moteris aktyviai ieško visų prieinamų ir galimų pagalbos šaltinių, nes baiminasi ir nerimauja dèl savo gerovės. Ji mačiusi atvejų, kai atsisakęs darbinès veiklos globėjas suserga pats. Moterị neramina ir tai, jog iki pensinio amžiaus turètų dar dešimt metų dirbti. Svarstydama ji daro tvirtą išvadą - tikrai neatsisakysianti darbo mamos priežiūros labui, nes išprotètų. Globẻja labai gerai save pažįsta ir jau patyrè, ką reiškia, kai namuose gyvena Alzheimerio liga sergantis žmogus, kaip sutrinka emocinė pusiausvyra, kaip tai veikia visus šeimos narius. Rita pasakoja, kad dabar jos mama išgyvena agresijos ir pykčio ligos etapa, o ji girdejusi, kad jam praejus sergantysis ilgainiui tampa švelnus, nuolankus. Taigi belieka laukti to meto. Tyrëjas mato, kad globejja baiminasi, jog aplinkybės susiklostys taip, kad ji bus priversta atsisakyti darbo dèl mamos priežiūros. Ir tai kelia jai nuolatinį nerimą. Taigi nuolat domisi, ieško informacijos apie pagalbos šaltinius šia liga 
sergantiems žmonėms, kad kaip nors pavyktų išlaikyti darbą. Tai vienas esminių dalykų, leidžiančių tyrimo dalyvei atsitraukti nuo globos proceso keliamų išgyvenimų.

Aš visa laika, vat, dabar galvoju, gal kažkada reikés mest darba ir eit mama prižiūrèt, $<\ldots>$ bet dabar, kuo toliau, tuo labiau suvokiu, kad tikrai taip nedarysiu. Geriau samdysiu žmogu arba organizuosiuos visokius ten. $<\ldots>$ Bet pati pamačiau, <..> kaip suserga šalia esantys, tie slaugantys, <...> Ir tikrai nemesiu darbo specialiai mamos priežiūrai, nes tikrai išprotéčiau. [Rita, 53 metai].

Tyrimo dalyvė Beata, žvelgdama ị ateiti, sako, jog tikètis reikia, ir susimąsto. Globejja pradeda mąstyti apie savo senatvę, kaip pati tuo metu gyvensianti. Moteris svarsto - pensija maža, nes globodama mamą turèjusi atsisakyti darbo. Vadinasi, neturėsianti galimybės patekti i senyvo amžiaus žmonėms skirtą „p padorią“” istaigą. Kyla klausimas, kaip žmogui neturint vaikų, kurie galètų suteikti pagalba - susitvarkyti ir pasirūpinti ramia senatve? Kol dar yra jẻgų ir galimybių rūpintis kitais žmonėmis, tyrimo dalyvė yra patenkinta ir laiminga. Baimè, nerimas dèl ateities, kai jau negalès savimi pasirūpinti, nuolatos neduoda moteriai ramybès. Ji tikisi specialistų, socialinių darbuotoju pagalbos, patarimo, ką daryti.

O dabar tai ka, aš pati galvoju, nu, pensija maža, negaliu net i seneliu namus, padorius, niekas manęs nepriims. Kaip čia dabar ta senatvę susitvarkyt. Tai va, kai aš galiu kitais rüpintis, tai dar laiminga. Bet va, kad savim pasirūpinti kaip, tai va, nežinau. Tai va, nežinau. Tai va, jau dabar jūs jau man turésit patarti. [Beata, 60 metų].

Tyrimo dalyvès stengiasi gyventi dabartimi, neplanuoti ateities. Tokia savikontrolè yra būtina savisaugai, kad nebūtų emociškai skausminga globejjui ir jo šeimos nariams, kai svajonès, laisvalaikio planai žlunga dèl globos proceso keliamų iššūkių, artimojo savijautos ar elgsenos pokyčių. Šeima išmoksta atsitraukti, atsiriboti nuo išorinio pasaulio - draugu, pažistamų, artimųju planų praleisti laiką kartu, dalyvauti bendrose veiklose, sueigose. Globejjas ieško kitų galimų pagalbos šaltinių ir randa jų brolių ar seserų šeimose, kurios kelias dienas ar valandas pasidalija sergančiojo priežiūros atsakomybe. I pagalbą ateina ir gyvenamosios bendruomenès nariai, kurie taip pat prisiima dali sergančiojo priežiūros atsakomybės. Globejas daugiausiai bendrauja su pirminės sveikatos priežiūros specialistais, iš kurių tikisi sulaukti reikiamos informacijos 
apie sergančiojo sveikatos būklę ir galimus formalius pagalbos šaltinius. Mediku pagalba neretai apsiriboja tik medikamentinio gydymo bei slaugos procedūrų aptarimu. Globejos teigia neturinčios informacijos ir nežinančios, kokią pagalbą globos procese galètų suteikti socialinis darbuotojas. Kreipiantis informacijos apie teisines globejo statuso i̇vardijimo galimybes, susiduriama su ilgai trunkančiais teismo procesais ir specialistų bei globẻjų nuogąstavimais, jog sėkmingos jų pabaigos sergantysis gali nesulaukti. Globejjai pageidautų institucijų ir specialistų, kurie organizuotų sergančiojo užimtumą dienos metu, esminių igūdžių ugdymo mokyma, keleto valandų per dieną bendravimą su ligoniu bei kasdienių namų ruošos atlikimo pagalbą. Taip pat įvardijama būtinybė turèti daugiau medicinos žinių, sveikatos priežiūros specialistų pagalba. Globėjai yra išmokę neplanuoti savo šeimos bei sergančiojo ateities, stengiasi gyventi šia diena tikėdamiesi, jog kada nors globos procesas baigsis ir šeima turèsianti daugiau galimybių savo poreikiams patenkinti. Net ir prieš kelerius metus pasibaigus globos procesui, globejjos išgyvena ilgesi, fizinès sveikatos sutrikimus bei adaptacinio periodo visuomenejje elementus, kai bandoma rasti save darbo rinkoje ar ieškoti su buvusia globos patirtimi susijusių veiklų.

Šiame tyrime išryškejjo, kad moters-globèjos patirtis visuomenëje yra privati, asmeninè - tik jos ir šeimos reikalas. Ši patirtis nematoma (ar tiesiog tariamai nematoma) visuomenès - pagalbą teikiančiu i̇staigu , specialistų - visų tų, kurie lyg ir turètų žinoti bei padèti. Neformalios globos paslaugu terminas laikomas „nematomu“, nes realus globejo darbas, veiklos vyksta mūsų intymiausioje ir privačioje vietoje - namuose (Perdue, 2012). Autorius globejjus dar vadina "šešèline darbo jèga“, kuri sudaro sąlygas senatvine demencija sergančiam žmogui saugiai gyventi bendruomeneje, nors ligos simptomai vis labiau ryškejja. Sergantiesiems apsaugomoji globa reikalinga dvidešimt keturias valandas per parą (Bookman, Harrington, 2007, cit. Perdeu, 2012). Labai svarbu, kad ìvairių užsienio šalių tyrëjai globejus laiko "slaptais pacientais", "slaptomis aukomis", kurioms reikalinga pagalba dèl senyvo amžiaus artimojo ligos ir globos (Thompson, Doll, 1982; Zarit, Orr, Zarit, 1985, cit. Zarit, 2005). Jei dabar ignoruojame, nematome moteru globejuc patirties, susijusios su sergančio artimojo globa, ar ilgainiui jos ir jų šeimos netaps mūsų socialinio darbo pagrindiniais, matomais, ìvardijamais klientais, 
turinčiais daugialypių, sudètingu, kompleksinių sunkumų? O gal galima prevenciškai to išvengti jau dabar?..

\section{IŠVADOS}

Globejjų suvokimas apie pagalbos išteklius konstruojamas socialinių paslaugu defamilizacijos stokos aspektu. Lietuvoje dominuojanti neformali pagalba kaip pirminis ir esminis pagalbos šaltinis labai ryški tyrimo dalyviu istorijose. Suvokusi, jog viena nebepajejgia atlikti visų su artimojo globa susijusių veiklų, globeja pirmiausia - instrumentinės ir emocinès pagalbos - kreipiasi i šeimos narius ir artimuosius. Moteris išgyvena kaltę, nes artimojo priežiūrą laiko tik savo vienos atsakomybe. Formalios pagalbos šaltiniais tampa pirminės sveikatos priežiūros įstaigos, nevyriausybinès organizacijos, dirbančios su artimaisiais, nors pagalba, moteru požiūriu, fragmentiška ir menka. Socialinio darbuotojo veiklą moterys iš savo patirties vertina taip pat menkai. Globėjos teigia pasigendančios sveikatos priežiūros ir kitų sričių specialistų pagalbos, per kurią gauti žinių, igūdžių, jų manymu, būtinų globos procese.

\section{LITERATŪRA}

1. Alzheimerio globos ir slaugos ịstaigu Asociacija (AGİA) [žiūrèta: 2012 m. spalio 17 d.]. Prieiga per internetą: http://www.alzheimerioistaigos.lt/lt/slaugospadariniai-slaugytojoms.html.

2. Archbold, P. G. (1983). Impact of Parent Caring on Women. Family Relations, 3: 39-45.

3. Bitinas B., Rupšienè, L., Žydžiūnaitė, V. (2008). Kokybiniu tyrimu metodologija. I-II dalis. Klaipèda.

4. Charmaz, K., (2011). A Constructivist Grounded Theory Analysis of Losing and Regaining a Value Self. Five Ways of Doing Qualitative Analysis. Phemomenological Psychology, Grounded Theory, Discourse Analysis, Narrative Research, and Intuitive Inquiry . In: F. J. Wertz, K. Charmaz, L. M. Mcmullen, R. Josselson, R. Anderson, E. Mcspadden (eds.). New York: The Guilford Press.

5. Farran, C. J. (1997). Theoretical Perspectives Concerning Positive Aspects of Caring for Elderly Persons With Dementia: Stress / Adaptation and Existentialism. The Gerontologist, 3 (2).: 250-257. 
6. Jankūnaitè, D. (2009). Globėjo, besirūpinančio Alzheimerio liga sergančiu artimuoju, streso iveikimas. Bakalauro darbas. Vytauto Didžiojo universitetas, Kaunas.

7. Jankūnaitė, D., Užaitė, V. (2011). Globejjo, besirūpinančio Alzheimerio liga sergančiu artimuoju, streso i̇veikimas. Socialinis darbas. Patirtis ir metodai, 7 (1): 153-174.

8. Kinney, J. M. (1996). Home care and caregiving, Encyclopedia of Gerontology, 1 (ed. Birren J. E.). San Diego: Academic Press.

9. Krysil, J. L., Finn, J. (2010). Research For Effective Social Work Practise. Routledge. Taylor \& Francis Group. New York. London. UK.

10. Lemme, B. H. (2003). Suaugusiojo raida. Vilnius: Poligrafija ir informatika.

11. Lietuvos statistikos departamentas. Informacija. Socialinés paslaugos $2011 \mathrm{~m}$. [žiūrèta: $2013 \mathrm{~m}$. balandžio 23 d.]. Prieiga per internetą: http://www.socmin. lt/index.php?1157882014.

12. LR Socialinės apsaugos ir darbo ministro įsakymas. Dèl socialinių paslaugu katalogo patvirtinimo (Nr. A1-93, 2006, Vilnius, VŽ, Nr. 43-1570).

13. Lukoševičienè, I. (1996). Profesinio socialinio darbo pagrindai. Kaunas: Caritas.

14. Mažeikienė, N., Naujanienė, R., Ruškus, J., Motiečienė, R., Dvarionas, D., Žvirdauskas, D. (2013). Igalinančiu socialiniu paslaugu modelio konstravimas (monografijos rankraštis).

15. Montano, C. R., (2011). Living with Alzheimer's disease: daughter caregivers and their contemporary families. Doctor's Dissertation. Capella University [žiūrèta: $2013 \mathrm{~m}$. balandžio 9 d.]. Prieiga per internetą: http://gradworks.umi. com/3454482.pdf.

16. Naujanienè, R. (2004). Socialiniai senéjimo aspektai. Socialinè gerontologija: ištakos ir perspektyvos (red. Večkienè N.). Kaunas: Vytauto Didžiojo universitetas.

17. Nolan, M., Ingram, P., Watson, R. (2002). Working with family carers of people with dementia. 'Negotiated' coping as an essential outcome. Dementia, 1 (1): 75-93 [žiūrẻta: 2013 m. kovo 21 d.]. Prieiga per internetą: http://dem. sagepub.com/content/1/1/75.abstract.

18. Perdue, M. (2012). Exploring the Experiences of Family Caregivers, Cape Cod's Invisible Workforce: Upholding the Promise of Olmstead for People with Alzheimer's and Dementia - related Diseases. Doctor's Dissertation. Northeastern University, Boston, Massachusetts [žiūrèta: 2013 m. gegužès 2 d.]. Prieiga per internetą: http:// iris.lib.neu.edu/cgi/viewcontent.cgi?article=1008\&context=law_pub_pol_diss.

19. Pivorienè, J. (2004). Sociologijos pagrindai socialiniame darbe. Šeima. Sveikata. Kaunas: VDU.

20. Savundranayagam, M. Y., Montgomery, R. J. V., Kosloski K., (2010). A Dimensional Analysis of Caregiver Burden Among Spouses and Adult 
Children. The Gerontologist, 10 (1093) [žiūrèta: 2013 m. kovo 21 d.]. Prieiga per internetą: http://www4.uwm.edu/tcare/upload/The-Gerontologist-Burdenpaper-_advance-copy.pdf.

21. Tidikis R. (2003). Socialiniu mokslu tyrimu metodologija. Vilnius: Lietuvos teisės universitetas.

22. Užaitė, V. (2005). Artimuju patirtis globojant nepagydoma liga sergančius senus žmones. Magistro darbo tezès. Kaunas, Vytauto Didžiojo universitetas.

23. Valeikienè, V., Skalskis, R. (2008). Alzheimerio ligos ankstyvieji požymiai bendrosios praktikos slaugytoju darbe. Gerontologija, 9 (2): 99-102.

24. West, C., Zimmerman, D. H. (1987). Doing Gender. Gender and Society, 2: 125-151.

25. Whitlach, C., Noelker, L., (1996). Caregiving and Caring. Encyclopedis of Gerontology: Age, aging and the Aged, 1: 253-269.

26. Willig, C. (2008). Intruducing Qualitative Research in Psychology. Adventures in theory and methods. Open University Press. London. UK.

27. Woods, D. R., (2006). The logic of defamilialization. Problems of analysis for care work and the transformation of the welfare state. Paper submitted for ESPA Anet Conference. Germany: Uvinersity of Bremen.

28. Zarit, S. H. (2005). Caregiving Revisited: Old and New Perspectives on Families Assisting Elders Penn State University M. Powell Lawton Award Lecture Gerontological Society of America Orlando, FL [žiūrèta: 2013 m. gegužès 2 d.]. Prieiga per internetą: http://www.abramsoncenter.org/pri/documents/ZaritCaregiving\%20Revisited_with\%20figures.pdf.

29. Žydžiūnaitė, V., Stepanavičienè, R., Bubnys, R. (2008). Artimuju išgyvenimai, prižiūrint Alzheimerio liga serganti asmenị: Socialinio darbo kontekstas. Šiauliai: Leidybos centras. 